\title{
Sports High School Students' Perceptions about COVID-19
}

\author{
Research Article
}

\section{Aysel KIZILKAYA NAMLI ${ }^{1}$, Gozde UCGUL ${ }^{2}$}

${ }^{1}$ Munzur University, Faculty of Sports Sciences, Department of Sport Management,Tunceli, Turkey, ORCID: 0000-0001- 7980- 421X

${ }^{2}$ Munzur University, Graduate Education Institute, Tunceli, Turkey, ORCID: 0000-0002-4944- 4097

To cite this article: Kızılkaya-Namli, A., \& Ucgul, G. (2021). Sports high school students' perceptions about COVID-19, International Online Journal of Educational Sciences, 13(2), 567-578.

\begin{abstract}
ARTICLE INFO ABSTRACT
Article History: $\quad$ This research aimed to determine the perceptions of sports high school students regarding the

concept of COVID-19. The metaphors included in qualitative research approaches were used in the

Received: 18.11.2020 study. The study group of the study consists of 174 students attending sports high schools in Elazı and Malatya, which were formed with the purposeful sampling maximum diversity method, which

Available online:

21.04.2021
\end{abstract}

(C) 2021 IOJES. All rights reserved

Keywords:

Sports high school students, COVID-19, Metaphor

\section{Introduction}

The COVID-19 outbreak caused by the SARS-CoV-2 virus, which emerged in Wuhan, China on December 31, 2019, quickly spread to six continents and hundreds of countries and went down in history as the first pandemic caused by coronaviruses. The epidemic, which started in our country with the identification of the first positive case on March 11, 2020, continues to increase its effect (Dikmen, Kına, Özkan \& İlhan, 2020). On 11 March 2020, the outbreak was declared a pandemic by the World Health Organization (WHO) (WHO, 2020a). Since 11 March 2020, important changes have occurred in our health, education, economy, social and cultural activities. With the rapidly increasing number of COVID-19 cases worldwide, a wave of fear and anxiety has occurred in the society in many countries of the world; With the course of the epidemic, these fears

${ }^{1}$ Corresponding author's address: Munzur University

Telephone: +905056848464

e-mail: ayselkizilkayanamli@munzur.edu.tr

DOI: https://doi.org/10.15345/iojes.2021.02.016 
and worries started to increase ( $\operatorname{Lin}, 2020)$. The world health organization has determined that with the epidemic, the order of life has changed all over the world, and practices such as flexible working, working from home, and working in return have been adopted in order to reduce the impact of the epidemic and minimize it due to its highly contagious feature. In addition, measures such as part-time and full-time curfews, quarantine situations, self-isolation, and maintaining of social distance have been taken all over the world. In the context of these measures, places where people could contact each other were closed, and schools and universities were included in this scope (WHO, 2020b). Most organizations have moved from traditional faceto-face education to digital learning. Most of the students enrolled in various educational institutions around the world have shifted their learning modes from the physical classroom to digital learning education. The use of easily accessible computers, phones, laptops, and tablets at home at affordable costs has increased, and especially policymakers and their stakeholders expect learning and teacher to continue in this direction during the COVID-19 outbreak (Mulenga \& Marban, 2020).

The Ministry of National Education (MEB) closed schools at all levels taking into consideration the wellbeing of primarily students, teachers, and parents as well as others in the education sphere. During this process, consultations with the Ministry of Health and the Scientific Committee continued on negotiations, and due to the rapid increase in the number of cases during the epidemic process, it was decided to close the schools first until the end of April, and then this period was extended until the end of May. With this decision, the educational periods of approximately 18 million students at different levels from primary school to the end of secondary education were moved out of school (Özer, 2020a). Therefore, due to the COVID-19 outbreak, teachers and lecturers had to learn digital methods to teach and present content to students (Mulenga \& Marban, 2020).

Distance education systems provide various facilities for teachers and students. Teachers and students in different locations do not have any problems communicating. Additionally, with distance education, students can benefit from educational institutions in different countries of the world. In the process of distance education, synchronous communication options such as chat channels and video conferencing, asynchronous communication options such as e-mail and discussion groups enable continuous and effective communication between trainer-student, student-student, and teacher-trainer (Altıparmak, Kurt \& Kapidere, 2011; Karakose \& Kocabas, 2006). It is a fact that MEB's transition to distance education due to the epidemic and this process is very fast is a new experience for most of the teachers and students. The literature reveals that the change in education paradigms cannot be reflected successfully without providing the training of teachers first. Today, there is serious pressure to take advantage of the possibilities of technology to overcome learning gaps (Perienen, 2020). However, it is clear that the advantages of distance education cannot replace face-to-face education and that changing the teaching suddenly brings some limitations. (Lau, Yang \& Dasgupta, 2020). Disadvantages of distance education can cause a loss of motivation since there is no interaction similar to faceto-face education. Internet-based and individual distance education can prevent students from socializing. Students who are alone with self-learning practices may lose their learning habits. The risk of becoming dependent on communication technologies is increasing. The risk of encountering some psychological and sociological problems increases for students who are far from group work discipline. Conducting assessments and evaluations on the internet carries a risk in terms of exam security (Elitaş, 2017; Karakose, Kocabas \& Yesilyurt, 2014).

In addition to all these, it would not be wrong to state that the infrastructure of the Ministry of Education is suitable for distance education. Turkey, especially in the last decade that has made investments in technology infrastructure, said that the results took a big step forward. Fatih Project and EBA have provided students, parents, teachers, education administrators, and MoNE with experience in distance education. The first stage in MEB has been successfully overcome, but this is not enough. It is necessary to provide the 
infrastructure to provide simultaneous and interactive virtual training via EBA. In addition, it is important to provide the student base with the online education infrastructure that reaches each home. When these opportunities are provided, it can be said that it will be possible to produce very different tools and perspectives to the problem of "justice in education", as quality education can be delivered to the student without depending on the place (Arkan, 2020).

In addition to the distance education, it continues to provide, MEB has prepared psychosocial support programs in order to protect the psychological health of students in this difficult period. In this context, MEB has established a helpline for psycho-social support of students and parents. Psychological counsellors from the Directorate General for Special Education and Guidance respond to calls and help students and parents cope with the unwanted effects of COVID-19. In Guidance and Research Centres (RAM), 1375 experts have been appointed in order to support students' and parents' psychological health. This is the first comprehensive project by MEB through which students and parents can communicate directly with experts in all provinces of Turkey (Ozer, 2020b).

In this process, the transition to an unfamiliar teaching system and the prolongation of staying at home in line with the decisions taken due to the epidemic suggests that they are also affected psychologically. Especially high school students in adolescence are affected by the situation. Considering their developmental characteristics, it is stated that adolescents are inevitably affected by the uncertainty, restrictions, and social contact limitations brought about by the pandemic (Yektaş, 2020). In this study, it was aimed to determine the perceptions of sports high school students regarding the concept of COVID-19. There are various studies in the literature on the psychological effects of COVID-19 (Aşkın, Bozkurt Zeybek \& 2020; Killgore, Taylor \& Cloonan, 2020; Tönbül, 2020; Tison et al., 2020). However, no research involving high school students was found. For this reason, it is thought that the research will contribute to the literature.

\section{Method}

In qualitative research approaches, the use of metaphors is important in terms of getting deeper opinions from individuals and understanding their feelings, thoughts, and feelings (İnam, 2008). It is perceived as a valuable and creative tool to develop a new theory or insight (Andriessen \& Gubbins, 2009).This research is a qualitative study in phenomenology design that examines the perceptions of sports high school students about the concept of COVID-19 through metaphors. The phenomenology pattern focuses on the phenomena that we are aware of but do not have an in-depth and detailed understanding (Yıldırım \& Şimşek, 2008). Phenomenology studies provide to approach a certain event or phenomenon from different angles.

\section{Research Group}

The study group of the research consists of 177 students, $56 \%$ female and $44 \%$ male, who attend sports high schools in Elazığ and Malatya, which was formed in purposeful sampling method, which is among the non-random sampling methods. In the purposeful sampling type, it is to choose situations that contain rich information that will illuminate the questions studied in the research (Patton, 2014). Maximum diversity sampling aims to create a relatively small sample and to reflect the diversity of individuals who may be a party to the problem studied in the sample (Yıldırım \& Şimşek, 2008).

Table 1. Features of the Research Group

\begin{tabular}{llll}
\hline Variables & & f & \% \\
\hline \multirow{2}{*}{ Gender } & Female & 97 & 56 \\
& Male & 77 & 44 \\
\hline \multirow{3}{*}{ Grade } & 9th grade & 53 & 30 \\
& 10th grade & 39 & 22 \\
& 11th grade & 34 & 20 \\
\hline
\end{tabular}




12th grade $\quad 48 \quad 28$

\section{Data Collection Tool and Data Collection}

An interview form consisting of two parts was developed in order to determine the perceptions of the sports high school students in the study group regarding COVID-19. The final form was given to the interview form after the expert opinion was obtained. In the first part, information about the characteristics of the participants was included. In the second part, research data were collected through a semi-structured openended questionnaire. The interview method is one of the data collection methods commonly used in qualitative studies; It is a data collection tool used to reveal individuals' behaviours (emotions, attitudes, feelings, etc.) that cannot be detected through observation (Merriam, 2009; Patton, 2002). In order to reveal the metaphors that high school students participating in the research have about their perceptions of COVID-19, they were asked to complete sentences such as "COVID-19 is like ... Because ....". The phrase "because" has been used in order to justify the metaphors that the participants have produced.

\section{Data Analysis}

The metaphors reflecting the perceptions of sports high school students about COVID-19 were taken into consideration in the sources in the literature before being categorized. Accordingly, data analysis was carried out in three stages to examine the metaphors produced by sports high school students in the research group regarding "COVID-19". In the first stage, the metaphors developed by the students in the study group were examined, and metaphors that did not contain a metaphorical meaning or were not intended for the purpose of the study were eliminated. Then, the metaphors developed were described according to their sources and frequency of use, and they were tabulated. In the tables created the source of the metaphors the students wrote about the metaphor they used and the frequency of using them were examined. In addition, five forms of which only the first part and the second part of the interview forms were filled were not analysed. Since the first part contains only the characteristics of the participants, it was not found worth analysing.

The metaphors developed in the second stage were subjected to in-depth analysis in terms of the relationship between their subject and source. At this stage, it was checked whether the metaphors presented any logical justification for the subject. No metaphor could not contribute to the examination of students' perceptions about COVID-19.

In the third stage, after the above-mentioned screening and in-depth relationship analysis, content analysis was performed and metaphors that have common features with certain aspects were gathered under a conceptual category. While categorizing this, the source of the metaphor was taken into account. For example, the category of "influencing social life" was created. In this category, the student made an analogy about the effect of the concept of COVID-19 on his social life. "COVID-19 is like a nuisance. Because we cannot socialize, we cannot travel, we cannot meet, it affects education and business life negatively. "Metaphors using such analogies are grouped under the same category. In this context, six categories were created by considering the metaphors used by the students and the source of the metaphor. These categories are created regardless of whether the metaphor used is positive or not. Most of the metaphors consist of negative expressions.

Various measures were taken to ensure validity and reliability in this study (Merriam, 2013; Yıldırım \& Şimşek, 2008; Türnüklü, 2000; Patton, 2014; Pandey \& Patnaik, 2014). In order to ensure internal validity in the study, expert opinion was taken, and participant confirmation was obtained. In order to ensure the external validity of the study, the data collection tool and the data collection process were included in detail, the characteristics of the study group and the data collection process were included, and the measures taken regarding validity and reliability were explained. In order to ensure the internal reliability of the research, the 
findings were directly presented, and the data were recorded. In order to ensure the external reliability of the study, the number of consensus and disagreement among experts was determined and the reliability formula proposed by Miles and Huberman (1994) was used. The reliability specific to this study was calculated as $91 \%$.

\section{Results}

In this study, which was conducted to determine the perceptions of sports high school students regarding the concept of COVID-19, the metaphors developed by high school students were determined. The metaphors produced by high school students regarding COVID-19 are given in Table 2.

Table 2. Metaphors Developed by Students on COVID-19

\begin{tabular}{|c|c|c|c|c|c|c|c|c|}
\hline MO & $\begin{array}{l}\text { Developed } \\
\text { Metaphor }\end{array}$ & $\mathbf{f}$ & MO & Developed Metaphor & $\mathbf{f}$ & MO & $\begin{array}{l}\text { Developed } \\
\text { Metaphor }\end{array}$ & f \\
\hline 1 & Flu & 19 & 27 & Limitation of Freedom & 2 & 53 & Ghost & 1 \\
\hline 2 & Death & 18 & 28 & $\begin{array}{l}\text { Unable to protect } \\
\text { oneself }\end{array}$ & 2 & 54 & Curse & 1 \\
\hline 3 & Disease & 10 & 29 & Boredom & 1 & 55 & Love Trouble & 1 \\
\hline 4 & Virus & 9 & 30 & Headache & 1 & 56 & Sunflower seeds & 1 \\
\hline 5 & Trouble & 9 & 31 & Stress & 1 & 57 & junk food & 1 \\
\hline 6 & Evil & 5 & 32 & Air & 1 & 58 & Hate & 1 \\
\hline 7 & Gossip & 5 & 33 & My ex & 1 & 59 & Mold & 1 \\
\hline 8 & Mask & 4 & 34 & Knife & 1 & 60 & Infectious & 1 \\
\hline 9 & Fear & 3 & 35 & Glue & 1 & 61 & Ordeal & 1 \\
\hline 10 & Cancer & 3 & 36 & Dreams & 1 & 62 & Prison & 1 \\
\hline 11 & Never-ending & 3 & 37 & Seasons & 1 & 63 & Cough & 1 \\
\hline 12 & Evil person & 3 & 38 & Pomegranate & 1 & 64 & Relatives & 1 \\
\hline 13 & Water & 3 & 39 & Gun & 1 & 65 & Chilli pepper & 1 \\
\hline 14 & Poison Ivy & 3 & 40 & Ignorance & 1 & 66 & Affection & 1 \\
\hline 15 & Plague & 3 & 41 & Ripped sweater & 1 & 67 & Destruction & 1 \\
\hline 16 & Disaster & 2 & 42 & Inglorious & 1 & 68 & Creature & 1 \\
\hline 17 & $\begin{array}{l}\text { Something } \\
\text { Awful }\end{array}$ & 2 & 43 & Vital & 1 & 69 & Nightmare & 1 \\
\hline 18 & Leech & 2 & 44 & Inconsideration & 1 & 70 & Unbelievable & 1 \\
\hline 19 & Destructive & 2 & 45 & Dirt & 1 & 71 & Avalanche & 1 \\
\hline 20 & Pest & 2 & 46 & Pandemic & 1 & 72 & Thief & 1 \\
\hline 21 & Snake & 2 & 47 & Snail & 1 & 73 & Risk & 1 \\
\hline 22 & Life & 2 & 48 & Rain & 1 & 74 & Project Assignment & 1 \\
\hline 23 & Heart & 2 & 49 & Fire & 1 & 75 & Game & 1 \\
\hline 24 & Summary my life & 2 & 50 & Copd & 1 & 76 & Dangerous & 1 \\
\hline 25 & Shit & 2 & 51 & Precious & 1 & & & \\
\hline 26 & Microbe & 2 & 52 & Life struggle & 1 & & & \\
\hline
\end{tabular}

MO: Metaphor Order; f: Frequency

There are a total of 76 metaphors developed by sports high school students for perceptions of COVID19. The most frequently repeated metaphors by sports high school students are influenza $(f=19)$, death $(f=$ 18), illness ( $(f=10)$, virus ( $(=9)$ trouble $(f=9)$, evil $(f=5)$, It is included as gossip $(f=5)$ and mask $(f=4)$. In these metaphors, taking into account the sources of metaphors, they are classified into conceptual categories according to their common features. These categories are shown in Table 3. 
Table 3. Categories of Metaphors Developed by Students on COVID-19

\begin{tabular}{|c|c|c|c|}
\hline Categories & Metaphors & f & $\%$ \\
\hline Spreading Rate & $\begin{array}{l}\text { Evil (3), Disease (3), Virus (3), Gossip (3), Water (3), Evil person (3), Poison } \\
\text { Ivy (2), Flu (2), Never-ending (2), Inconsideration, Glue, Avalanche, } \\
\text { Microbe, Sunflower seeds, Dangerous, Cough, Curse, Mask, Snail, Rain, } \\
\text { Air, Pandemic, Relatives, Affection, Pomegranate, Hate, Ignorance }\end{array}$ & 42 & 24 \\
\hline Fear of Death & $\begin{array}{l}\text { Death (12), Trouble (4), Cancer (2), Fear (2), Disease (2), Destructive (2), } \\
\text { Life (2), Ghost, Vital, Risk, Never-ending, Unbelievable, Snake, Plague, } \\
\text { Virus, Fire }\end{array}$ & 35 & 20 \\
\hline $\begin{array}{l}\text { Influence } \\
\text { social life }\end{array}$ & $\begin{array}{l}\text { Death (4), Mask (3), Curse (2), Limitation of Freedom (2), Something } \\
\text { Awful (2), Gossip (2), Shit (2), Leech (2), Evil (2), Unable to protect oneself } \\
\text { (2), Nightmare, Dreams, Project Assignment, Never-ending, Boredom, } \\
\text { Prison, Thief, Seasons }\end{array}$ & 31 & 18 \\
\hline Symptoms & $\begin{array}{l}\text { Flu (16), Plague (2), Virus (2), Microbe, Headache, Mold, Leech, Disaster, } \\
\text { My ex, Leech, Copd, Infectious }\end{array}$ & 29 & 17 \\
\hline Damaging & $\begin{array}{l}\text { Disease (5), Trouble (3), Heart (2), Virus (2), Cancer, Destruction, } \\
\text { Inglorious, Dirt, Creature, Junk food, Disaster, Stress, Gun, Ripped } \\
\text { sweater, Snake, Knife, Game, Poison Ivy, Love trouble, Fear }\end{array}$ & 28 & 16 \\
\hline $\begin{array}{l}\text { Showing care } \\
\text { and value }\end{array}$ & $\begin{array}{l}\text { Summary my life (2), Precious, Death (2), Virus, Flu, Chilli Pepper, Life } \\
\text { struggle, Ordeal }\end{array}$ & 9 & 5 \\
\hline
\end{tabular}

The metaphors produced by sports high school students regarding the concept of COVID-19 were classified by considering their sources. According to the classification made, it was determined that most of the metaphor sources produced were negative. When it is classified according to metaphor sources, it has been revealed that it is grouped into six categories. The metaphor about the spreading rate of sports high school students the most $(f=42)$ was produced. Later, it was aimed at fear of death $(f=35)$, affecting social life $(f=$ 31 ), symptom of the disease ( $f=29)$, damaging the disease $(f=28)$, and finally showing some values of the disease $(f=29) .=9)$ metaphors were produced.

Participant quotations belonging to the category of the metaphors produced regarding the "spreading rate" are given below.

"It is like evil. It takes people's lives, they do not know where they got sick from, it can be anywhere at any time" (S35). "It's like the flu. Because it is a disease that spreads very rapidly and is treated in a very difficult way." (S39). "It's like an evil person. An evil person brings evil to every environment he goes to, and the virus brings disease to every environment it enters" (S64). "It's like gossip. It spreads from person to person as it is told" (S78). "It is like my relatives. They do not leave me, they do not go away, like the virus, they become a thousand from one" (S100). "It's like love. It increases when shared" (S106). "It is like a pomegranate. it appears as one but consists of a thousand" (S108).

Participant quotations belonging to the category of the metaphors produced regarding "fear of death" are given below.

"It is like fire because it brings closer to death, it reminds me of hell" (S40). "It's like a ghost. You know it exists, but you can't see it. You expect it to take your life at any moment before you can do anything. " (S54). "It's like risk. You risk facing death at any moment" (S68). "It's like incredible. We have seen viruses and epidemics before, but we have never come face to face with such deaths" (S81). "It's like a snake. By harming a person, it can tear him away from life" (S92). "It's like cancer. Cancer has no salvation the disease that has no cure." (S110).

Participant quotations belonging to the category of the metaphors produced regarding "influence on social life" are given below. 
"It's like boredom. We cannot socialize, we cannot travel, we cannot meet, it affects education and business life negatively" (S36). "Like my dreams, they seem to exist but actually they do not exist" (S38). "It's like a terrible thing because we can't go out, we are stuck in the houses" (S45). "It is like a never-ending project assignment. In fact, if we focus on it worldwide, it will not take more than 1 month, but we are stubbornly extending it. We saw our inadequacies like a student trying to complete an assignment." (S56). "It's like shit. How does it affect the whole environment with that stench, and this affects my environment because I can get sick" (S104)? "It's like a thief. It stole the best years of my youth, my high school life" (S122). "It's like the seasons. You think the sun is shining suddenly and then it starts to snow" (S137).

The quotations of the participants regarding the "symptom" category of the produced metaphors are given below.

"It's like the flu. All features are similar, slightly severe form of flu" (S4). "Like flu. It includes similar types of complications" (S52). "It's like the plague. Because it is an infectious disease from humans such as plague disease" (S55). "It is like a virus. Its coming into our lives, making us sick, having to be isolated are all the effects of the virus" (S60). "It's like a disaster. It is contagious and is now spreading all over the world" (S69).

Participant quotations regarding the "damaging" category of the metaphors produced are given below.

"COVID-19 is inglorious. Because it kills those who believe in it and leaves permanent damage to people it infects but does not kill" (P46). "It is like a creature. It scares and harms people. And it does not come out of our dreams" (P57). "It is like junk food. Just as it harms the body, the virus also damages us" (P71). "It is like a ripped sweater. Because if you do not take precautions, it may disappear completely" (K98). "It is like a snake. There is no compensation for the pain and loss it caused" (P101). "It is like a malady. Because it finished my youth, we could not play a match, we could not walk around in the streets because of unnecessary prohibitions" (P116). "It is like a game. If you do not play games in your childhood, you will be very lacking in the future. If you do not take action now, your health will be ruined in the future" (P120).

Participant quotations belonging to the category of the metaphors that are related to the "signifier" are given below.

"It's like the summary of my life. I understand the value of some things when I lose them. At these times, people understand how valuable breathing is when they get sick" (P43). "It is like life. Because it makes us feel that even breathing in our most vulnerable moment is worth living. Like life" (P49). "It is like precious. It helped to understand what is important in our lives" (P66). "It is like death. It reminded us how precious life is" (P95).

\section{Discussion and Conclusion}

In this study, it was aimed to determine the perceptions of sports high school students regarding the concept of COVID-19. According to the results of the research, almost all of the students produced negative metaphors. Sports high school students mostly produced metaphors about the spreading rate. Although adolescents can establish cause and effect connections to understand the life-saving constraints to prevent the spread of the disease, their incomplete cognitive maturation; may cause them not to evaluate risky situations sufficiently and perceive the situation they experienced much more risky or less risky than they are (Yektaş, 2020). For this reason, it can be said that the students' emphasis on the speed of the disease spreading the most is due to the anxiety they experienced.

It was determined that sports high school students produced the most metaphors about fear of death after the spreading rate. It is possible to experience many different mental difficulties during the epidemic. The person may be worried about the loss of life of himself and his loved ones, he may feel deterioration in sleep quality and a decrease in his sense of confidence for the future; s/he may have nightmares and may find it difficult to focus on the job. Attitudes as if they are at a younger age can be observed in children and young age groups. Psychiatric disorders are likely to occur in many children and adolescents, not only during this process but also when this process ends (Önen, 2020). It can be said that the loss of high school students around them is a factor in the formation of this fear. It can be thought that it is normal for students who experience death in their immediate environment to experience panic in this regard. 
There are metaphors produced by sports high school students about affecting social life. It can be said that because they are in the quarantine period for a long time and the age groups are also under curfew, it causes students to be affected a lot. In addition, it is normal for adolescents who cannot spend time with their peers and communicate face-to-face to be affected by the epidemic. In a study, considering the positive effects of spending time with their peers for children and adolescents, it is stated that limited meetings with their peers can lead to mental problems such as frustration, anger and behavioural disorders in children (Koçak \& Harmanc1, 2020). Therefore, it can be stated that adolescents have a different mood. In a study by Sønderskov, Dinesen, Santini, and Østergaard (2020), it was stated that psychological well-being (mental health) was negatively affected by the COVID-19 pandemic, and women were more affected than men. In terms of mental illnesses in the quarantine period, adolescents who are involved in risk groups are forced to adapt to quarantine rules and it is indicated that they are involved in the group that frequently breaks the quarantine rules similar to the health professionals (Psychiatric Association of Turkey, 2020b). Causes such as prolongation of the quarantine period, fear of infection, disappointment and boredom, insufficient information about the process, lack of face-to-face training with friends and teachers, lack of personal space at home, and financial losses in the family cause stress or more problematic and permanent effects on children and adolescents. (Brooks, Webster, Smith, Woodland, Wessely, Greenberg \& Rubin, 2020; Altinkurt \& Karakose, 2009). Research has also revealed the negative effects of the pandemic.

In the research, it was determined that sports high school students produced metaphors about the symptoms of COVID-19, metaphors about its damage and metaphors about showing the value of life. In a study on the subject, it was stated that as the COVID-19 outbreak continues to spread, the research findings will provide vital guidance for the development of a psychological support strategy and the fields to be prioritized in the areas affected by the epidemic. It was stated that the priority of the study was to identify high-risk groups for early psychological interventions based on socio-demographic information. In sociodemographic data, it has been determined that women are exposed to higher levels of stress, anxiety, and depression as well as more psychological effects of the epidemic. Students were also found to experience a psychological impact of the epidemic and higher levels of stress, anxiety, and depression. In the first phase of the COVID-19 outbreak in China, more than half of the participants rated the psychological effects as moderate to severe, and about a third reported moderate to severe anxiety (Wang et.al, 2020).

Many studies have determined that the quarantine period has serious psychological effects on children and adolescents. In a study on the subject, it was stated that a significant number of children did not experience a severe mental disorder, although they showed some symptoms of anxiety, insomnia, and concentration problems for a temporary period. However, it states that especially those who have had various mental problems or traumatic experiences, those who have family problems, or who lost their relatives are at increased risk of mental disorders. It also indicates that risky behaviours such as sleeping and eating problems, excessive irritability, aggression, withdrawal, sadness, intense anxiety, physical pain, behavioural problems, alcohol use can be found in adolescents (Psychiatric Association of Turkey, 2020). A study conducted in China revealed that the most common psychological and behavioural problems among children and adolescents during the quarantine process are clinging behavior, separation anxiety, distraction, irritability, and fear of asking questions about the epidemic (Jiao, Wang, Liu, Fang, Jiao, Pettoello. -Mantovani \& Somekh, 2020). In the study conducted by Karataş (2020), it was determined that students preparing for LGS and YKS exams experienced some psychological problems and difficulties during the COVID-19 pandemic process. In addition, it was stated that the mental health of those who experienced a forced quarantine situation should be intervened urgently (Wu, Guo, Shang, Sun, Jia, Sun \& Liu, 2020). In the study conducted by Çelebi (2020), it was stated that approximately half of the participants had their sleep patterns negatively affected by this process. In the study by Ozamiz-Etxebarria, Dosil-Santamaria, Picaza-Gorrochategui, and Idoiaga-Mondragon (2020), young individuals with chronic diseases reported more symptoms than the rest of the population, 
although symptom levels were generally low at the onset of the outbreak warning. In addition, the study revealed that higher symptom levels were detected after the quarantine process. It has also been determined that COVID-19 causes depression, panic disorder, and anxiety in humans (Cao, Fang, Hou, Han, Xu, Dong \& Zheng, 2020; Qiu, Shen, Zhao, Wang, Xie, \& Xu, 2020; Karakose \& Malkoc, 2021).

In addition, the provision of distance education to students during the pandemic process has necessarily increased the use of technology. In addition to the compulsory exposure to education-related technology, the use of technology among individuals has also increased. Gao et al. (2020) found that $80 \%$ of the participants in the study were exposed to more social media during the pandemic period. As a result of the research conducted by Öztürk, Akalın, Özgüner, and Şakiroğlu (2020), it was revealed that the negative effects of the epidemic and quarantine increased as both phone usage time and Twitter usage increased. In another study, it was determined that the increase in depression due to the pandemic also increased the social media addiction (Dikmen, 2021).

It includes the maladaptive behaviours, psychological reactions, emotional distress and defensive reactions of people against epidemics (Cullen, Gulati \& Kelly 2020). Research and studies in the literature also support this situation. Adults need to be authentic about some of the uncertainties and psychological difficulties of the pandemic, without overwhelming children with their own fears. This honesty not only provides a consistent explanation of what children observe, but also allows children to speak confidently about their feelings. Normalizing their emotional responses and securing children about how families look after each other helps control anxiety and provides a common focus (Dalton, Rapa \& Stain, 2020).

As a result of the research, it was determined that sports high school students who were in a critical phase of adolescence were negatively affected by the pandemic process. It can be said that both the exposure to an unusual event and the compulsory interruption of the education process have an effect on high school students. The results of the research and research in the literature revealed that students and individuals were seriously affected by this process. The number of students who evaluate this process positively (showing the value of life) is very few.

\section{Recommendations}

At the end of this research, it may be suggested;

- School counselling service and classroom teachers to be in constant communication with students so that students can overcome and pass these situations more easily,

- The Ministry of National Education to use psychosocial support programs more effectively. 


\section{REFERENCES}

Akalın, S., Özgüner, İ., \& Şakiroğlu, M. (2020). Psychological Effects of Covid-19 Outbreak and Quarantine. Electronic Turkish Studies, 15 (4), 885-905.

Altinkurt, Y., \& Karakose, T. (2009). Ilkogretim okulu mudurlerinin etik liderlik davranislarina iliskin ogretmen gorusleri. Dumlupinar Universitesi Sosyal Bilimler Dergisi, 24, 269-280.

Altıparmak, M., Kurt, İ. D., \& Kapıdere, M. (2011). Open source learning management systems in e-learning and distance education. 11th Academic Informatics Conference Proceedings, 321-327.

Andriessen, D., \& Gubbins, C. (2009). Metaphor analysis as an approach for exploring theoretical concepts: the case of social capital. Organization Studies, 30(08), 845-863.

Arkan, A. (2020). Post-coronavirus education. Access to: https://www.setav.org/koronavirus-sonrasi-egitim/

Bozkurt, Y., Zeybek, Z. ve Aşkın, R. (2020). Covid-19 pandemic: Psychological effects and therapeutic interventions. Istanbul Commerce University Journal of Social Sciences, 19(37), 304-318.

Brooks, S. K., Webster, R. K., Smith, L. E., Woodland, L., Wessely, S., Greenberg, N., \& Rubin, G. J. (2020). The psychological impact of quarantine and how to reduce it: rapid review of the evidence. The Lancet, 395(10227), 912-920. https://doi.org/10.1016/S0140-6736(20)30460-8

Cao, W., Fang, Z., Hou, G., Han, M., Xu, X., Dong, J., \& Zheng, J. (2020). The psychological impact of the COVID-19 epidemic on college students in China. Psychiatry Research, 287. https://doi.org/10.1016/j.psychres.2020.112934

Cullen, W., Gulati, G., \& Kelly, B.D. (2020). Mental health in the Covid-19 pandemic. Published by Oxford University Press on behalf of the Association of Physicians. https://mc.manuscriptcentral.com/qjm

Çelebi, G. Y. (2020). Investigation of covid-19 outbreak responses in terms of psychological resilience. IBAD Journal of Social Sciences, (8), 471-483.

Dalton, L., Rapa, E., \& Stein, A. (2020). Protecting the psychological health of children through effective communication about COVID-19. The Lancet Child \& Adolescent Health, 4(5), 346-347. https://doi.org/10.1016/S2352-4642(20)30097-3

Dikmen, A. U., Kına, M. H., Özkan, S., \& İlhan, M. N. (2020). COVID-19 epidemiology: What we learned from the pandemic. Journal of Biotechnology and Strategic Health Research, 4, 29-36.

Dikmen, M. (2021). Examining the role of university students' depression levels on social media addiction in the COVID-19 outbreak: a structural equation model. Journal of Addiction, 22(1), 20-30.

Elitaş, T. (2017). New communication technologies in the distance education undergraduate process: Atatürk University distance education center. Doctoral Thesis, Institute of Social Sciences, Marmara University, İstanbul.

Gao, J., Zheng, P., Jia, Y., Chen, H., Mao, Y., Chen, S., Wang, Y., Fu. H., \& Dai, J. (2020). Mental health problems and social media exposure during COVID-19 outbreak. Plos one, 15(4). https://doi.org/10.1371/journal.pone.0231924

İnam, Ö. (2008). Use of metaphors in television advertisements. Doctoral Thesis, Institute of Social Sciences, Anadolu University, Eskişehir.

Jiao, W. Y., Wang, L. N., Liu, J., Fang, S. F., Jiao, F. Y., Pettoello-Mantovani, M., \& Somekh, E. (2020). Behavioral and emotional disorders in children during the COVID-19 epidemic. The Journal of Pediatrics, 221, 264.

Karakose, T., \& Kocabas, I. (2006). The effect of teachers' expectations on job satisfaction and motivation in private and public schools. Journal of Theory and Practice in Education, 2(1), 3-14. 
Karakose, T., Kocabas, I., \& Yesilyurt, H. (2014). A quantitative study of school administrators' work-life balance and job satisfaction in public schools. Pakistan Journal of Statistics, 30, 1231-1241.

Karakose, T., \& Malkoc, N. (2021). Psychological impact of the COVID-19 pandemic on medical doctors in Turkey. Social Behavior and Personality, 49(1), e9890.

Karataş Z. (2020). Examining the reflections of the COVID-19 pandemic process on the psychology of children and adolescents who are in the process of preparing for the LGS and YKS exams. Gençdoğan B. (Ed.), In Child and Adolescent Psychology During Pandemic Period (s.54-74). Ankara: Turkey Clinics.

Killgore, W. D. S., Taylor, E. C., \& Cloonan, S. A. (2020). Psychological resilience during the COVID-19 lockdown. Psychiatry Research, 291. https://doi.org/10.1016/j.psychres.2020.113216.

Koçak, Z. \& Harmanc1, H. (2020). Mental health in the family during the Covid-19 pandemic. Karatay Journal of Social Research, (5), 183-207.

Lau, J., Yang, B., \& Dasgupta, R. (2020). Will the coronavirus make online education go viral Access address: https://www.timeshighereducation.com/features/will-coronavirus-makeonline -education-go-viral.

Lin, C. Y. (2020). Social reaction toward the 2019 novel coronavirus (COVID-19). Social Health Behaviour, 3, 1-2.

Merriam, S. B. (2009). Qualitative research: A guide to design and implementation. San Francisco, CA: Jossey- Bass Merriam, S. B. (2013). Qualitative Research (Çev. Ed. Selahattin Turan). Ankara: Nobel Pulishing.

Miles, M. B. \& Huberman, A. M. (1994). Qualitative data analysis (2nd edition). Thousand Oaks, CA: Sage.

Mulenga, E. M.,\& Marbán, J. M. (2020). Is COVID-19 the gateway for digital learning in mathematics education? Contemporary Educational Technology, 12(2), ep269. https://doi.org/10.30935/cedtech/7949

Ozamiz-Etxebarria, N., Dosil-Santamaria, M., Picaza-Gorrochategui, M., \& Idoiaga-Mondragon, N. (2020). Stress, anxiety, and depression levels in the initial stage of the COVID-19 outbreak in a population sample in the northern Spain. Cadernos de Saúde Pública, 36. https://doi.org/10.1590/0102-311X00054020

Önen, Ö. (2020). The coronavirus epidemic and children. Access address: https://psikeart.com/bulten/pandemi/koronavirus-salgini-ve-cocuklar/

Özer, M. (2020a). The contribution of the strengthened capacity of vocational education and training system in turkey to the fight against COVID-19. Journal of Higher Education, 10(2), 134-140. https://doi.org/10.2399/yod.20.726951.

Özer, M. (2020b). Educational policy actions by the Ministry of National Education in the times of COVID-19 pandemic in Turkey. Kastamonu Education Journal, 28(3), 1124-1129.

Pandey, S. C., \& Patnaik, S. (2014). Establishing reliability and validity in qualitative inquiry: A critical examination. Jharkhand Journal of Development and Management Studies, 12(1), 5743-5753.

Patton, M. Q. (2002). Qualitative evaluation and research methods (3rd ed.). Thousand Oaks, CA: Sage Publications, Inc.

Patton, M. Q. (2014). Qualitative research and evaluation methods (Çev. Ed. M. Bütün ve S. B. Demir). Ankara: Pegem Publishing.

Perienen, A. (2020). Frameworks for ICT Integration in Mathematics Education - A Teacher's Perspective. Eurasia Journal of Mathematics, Science and Technology Education, 16(6), em1845. https://doi.org/10.29333/ejmste/7803 
Qiu, J., Shen, B., Zhao, M., Wang, Z., Xie, B., \& Xu, Y. (2020). A nationwide survey of psychological distress among Chinese people in the COVID-19 epidemic: implications and policy recommendations. General Psychiatry, 33(2). https://dx.doi.org/10.1136\%2Fgpsych-2020-100213

Sønderskov, K. M., Dinesen, P. T., Santini, Z. I., \& Østergaard, S. D. (2020). The depressive state of Denmark during the COVID-19 pandemic. Acta Neuropsychiatrica, 32(4), 226-228. https://doi.org/10.1017/neu.2020.15

Tison, G. H., Avram, R., Kuhar, P., Abreau, S., Marcus, G. M., Pletcher, M. J. ve Olgin, J. E. (2020). Worldwide effect of COVID-19 on physical activity: A descriptive study. Annals of Internal Medicine, 173(9), 767-770.

Tönbül, Ö. (2020). Examining the psychological resilience of individuals aged 20-60 in terms of some variables after the coronavirus (Covid-19) epidemic. Humanistic Perspective, 2(2), 159-174.

Türkiye Psikiyatri Derneği (2020a). COVID-19 and children. Access address: https://www.psikiyatri.org.tr/uploadFiles/2420201236-cocuklarCOVID.pdf

Türkiye Psikiyatri Derneği (2020b). Psychological effects of quarantine and preventive measures. Access address: https://www.psikiyatri.org.tr/TPDData/Uploads/files/KarantinaCOVID.pdf

Türnüklü, A. (2000). A qualitative research technique that can be used effectively in pedagogical research: Interview. Educational Administration in Theory and Practice, (24), 543-559.

Wang, C., Pan, R., Wan, X., Tan, Y., Xu, L., Ho, C. S., \& Ho, R. C. (2020). Immediate psychological responses and associated factors during the initial stage of the 2019 coronavirus disease (COVID-19) epidemic among the general population in China. International Journal of Environmental Research and Public Health, 17(5), 1729.

World Health Organization (2020a). WHO director-general's opening remarks at the media briefing on COVID-19. Access to: https://www.who.int/dg/speeches/detail/who-director-general-sopeningremarks-at-the-media-briefing-on-COVID-19---11-march-2020.

World Health Organization (2020b). Turkey Covid-19 report Access to: https://www.euro.who.int/en/countries/turkey/publications/turkeys-response-to-covid-19-firstimpressions- ankara,-turkey,-11-july-2020

Wu, L., Guo, X., Shang, Z., Sun, Z., Jia, Y., Sun, L., \& Liu, W. (2020). China experience from COVID-19: Mental health in mandatory quarantine zones urgently requires intervention. Psychological Trauma: Theory, Research, Practice, and Policy, 12(S1), S3-S5. https://doi.org/10.1037/tra0000609

Yektaş Ç. (2020). Mental effects of the pandemic in adolescents. Ercan E.S., Yektaş Ç., Tufan A.E., Bilaç Ö. (Ed.) COVID-19 Pandemic and Child and Adolescent Mental Health in (s.8-13). Ankara: Turkey Clinics.

Yıldırım, A., \& Şimsek, H. (2008). Qualitative research methods in the social sciences. Seçkin Publishing. 